\title{
Kan ons nog in God glo?
}

\section{Book Title:}

Wie is God? Kan ons regtig in Hom glo?

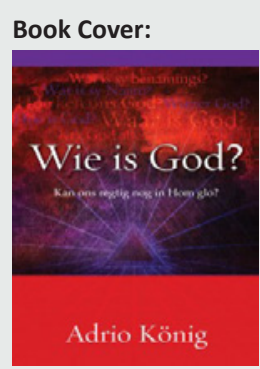

Author:

Adrio König

ISBN:

978177000959-2

Publisher:

Vereeniging: Christelike

Uitgewersmaatskappy (2012)

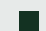

Review Title:

Kan ons nog in God glo?

Reviewer:

F.P. Kruger ${ }^{1}$

Affiliation:

${ }^{1}$ Reformed Church,

Meyerspark, South Africa

Email:

ferdikruger4@gmail.com

Postal address:

Posbus 75973, Lynnwoodrif

0040, South Africa

How to cite this book review:

Kruger, F.P., 2012, 'Kan ons

nog in God glo?', Koers

- Bulletin for Christian

Scholarship 77(2), Art.

\#342, 1 page. http://dx.doi.

org/10.4102/koers.v77i2.342

(C) 2012. The Authors.

Licensee: AOSIS

OpenJournals. This work

is licensed under the

Creative Commons

Attribution License.
In hierdie omvattende boek word besin oor of 'n mens nog in God kan glo. Dit is daarom baie aktueel. In navorsing is al meermale aangetoon dat die huidige konteks ook ' $n$ post-Christelike era genoem kan word. In die onderskeie studievelde is daarom al op diepgaande wyse gefokus op die uniekheid van die Christelike geloof. In hierdie boek word vanuit die perspektief van die Dogmatiek op hierdie aspek gekonsentreer. 'n Boek waarin debat gevoer word met hedendaagse outeurs en voorstaanders van bepaalde opinies rakende God, word nie gereeld op die rak aangetref nie.

Waaroor handel die boek? Die sentrale teoretiese argument is dat God uniek is. Teenoor diegene wat die Bybelse boodskap oor God in diskrediet wil bring, stel die outeur hom dit ten doel om in sy studie te ondersoek wat die Bybel oor God sê. Die boek handhaaf 'n goeie balans tussen dit wat God se Woord oor Hom openbaar, met heelwat bewyse uit die Skrif en 'n wetenskaplike metodiek wat vernuftig met sekere standpunte omgaan. Hierdie boek behoort nuttig te wees vir predikante en diegene wat belangstel in 'n wetenskaplike hantering van bronne. Terselfdertyd is dit in eenvoudige taal gegiet sodat diegene wat nie teoloë is nie, ook hierby sal baat vind. Daar is heelwat prikkelende onderwerpe wat aangeraak word, soos die evolusie, die Godsbewyse, name vir God asook die vraag na waar God is en of Hy 'n woonplek het.

Die boek bestaan uit dertien hoofstukke. In hoofstuk 1 word gehandel met die vraag of daar 'n God is. Dit wat die Bybel oor God openbaar, word gestel teenoor die uitgangspunte van die evolusionisme. In hoofstuk 2 word besin oor die vraag of God tot dieselfde werklikheid as mense behoort. Deeglike aandag word verleen aan diegene wat op soek is na God, die sieninge oor panteïsme en postteïsme asook die troos van die opstanding van Christus. Hoofstuk 3 besin oor die vraag of God geken kan word en hoeveel ons as mense van Hom weet. Die outeur toon aan dat hierdie vraag nie deur logiese denke beantwoord kan word nie, maar deur 'n gelowige luister na wat God self in sy Woord sê. In hoofstuk 4 word die baie aktuele vraag aangeraak of alle godsdienste dieselfde God dien. Teenoor die eksponente wat hiervoor pleit, stel König die uitgangspunt van God se uniekheid. In hoofstuk 5 word 'n uitgebreide beredenering oor die wese van God aangetref. Daar word ook 'n onderskeid getref tussen die wese van God en die eienskappe van God. Die organiese verhouding tussen die Ou en Nuwe Testament is in hierdie navorsing besonder opvallend. In hoofstuk 6 word die Naam van God, Jahweh, bespreek, terwyl daar in hoofstuk 7 gelet word op ander benaminge vir God.

In hoofstuk 8 bied die outeur 'n uiteensetting van die eienskappe van God. Hoofstuk 9 raak die belangrike saak van die almag van God aan. Augustinus, Thomas van Aquinas en Calvyn se sieninge hieroor word bespreek, wat baie nuttig is in die lees van die boek. In hoofstuk 10 word besin oor die vraag of God ook stryd ken. Daarmee word die eeue-oue vraag na die sin van lyding op die tafel geplaas. Hoofstuk 11 en 12 ondersoek die verskynsel van antropomorfismes as wyse waarop mense oor God praat en oor die vraag of God veranderlik is. Hoofstuk 13 sluit af met die hoogtepunt van 'n bespreking oor die Drie-eenheid van God. Aan die einde van die boek word 'n nuttige onderwerpregister gebied, alhoewel 'n teksregister gemis word.

Die boek is geskryf in 'n populêr-wetenskaplike styl. Dit kan van harte aanbeveel word vir predikante en ook vir gemeentes wat erns maak met wat die Bybel oor God sê. Dit dien as wins dat hierdie boek op diepgaande wyse oor God besin. Die boek volg 'n goeie indeling van hoofstukke en die logiese bou versterk die lyn van redenasie. Die boek is baie goed versorg en lees gemaklik. Die resensent sou dit verkies het dat hoofstuk 13, naamlik die Drie-eenheid, eerste aan die orde moes kom, maar dit lê op die vlak van persoonlike voorkeur. Die lesers van hierdie boek sal baie baat vind by die besondere manier waarop die outeur omgaan met sy stof en met diegene van wie hy op wetenskaplike gebied verskil. Die boek slaag daarin om moeilike onderwerpe op kommunikatiewe wyse aan te spreek en skram nie daarvan weg om 'n eie en selfstandige opinie te huldig nie. Die boek lewer 'n kreatiewe en positiewe bydrae tot die aktuele debat oor God en kan van harte aanbeveel word. Die groot waarde van die boek lê ongetwyfeld opgesluit in die wyse waarop die Skrif ontsluit word sodat lesers kan ontgin wat God se Woord self oor Hom openbaar. 